\title{
In vitro photoprotective, antioxidant and antibacterial activity of Vernonia squarrosa (D. Don) Less
}

\author{
Adwaita Das $^{1}$, Sunanda Burman ${ }^{2}$, Goutam Chandra ${ }^{2}$ \& Abhijit Bandyopadhyay ${ }^{1^{*}}$ \\ ${ }^{1}$ Cytogenetics and Molecular Biology Laboratory, Department of Botany, The University of Burdwan, Burdwan-713 104, West Bengal, India \\ ${ }^{2}$ Mosquito, Microbiology and Nanotechnology Research Units, Parasitology Laboratory, Department of Zoology, The University of Burdwan, \\ Burdwan-713 104, West Bengal, India \\ *Email: palmajua@gmail.com
}

\section{ARTICLE HISTORY}

Received: 23 November 2020

Accepted: 04 February 2021

Published: 01 April 2021

\section{KEYWORDS}

Antioxidant potential

Lupeol

Photoprotective

Vernonia squarrosa

\section{ABSTRACT}

Vernonia squarrosa (D. Don) Less. (Asteraceae) is an ethnomedicinally important plant of unexplored medicinal potential. The Hydro-Methanolic Leaf Extract (HMLE) reveals presence of alkaloids, terpenoid, tannins, phenols, flavonoids, saponins and also cardiac glycosides with notable amount of phenol, flavonoid, $\beta$ carotene and lycopene. The high antioxidant activity of HMLE when assessed by 2 , 2 diphenyl 1-picrylhydrazyl (DPPH) shows significant $\mathrm{EC}_{50}$ value of $11.63 \pm 2.60 \mu \mathrm{g} / \mathrm{ml}$. Photoprotection efficiency of HMLE was determined and expressed as Sun Protection Factor (SPF). Reasonably high SPF value of $38(\mathrm{SPF}=38$ at $200 \mu \mathrm{g} / \mathrm{ml}$ ) provides UV blockage up to $98 \%$. HMLE extract was also screened for antibacterial activity against four human pathogenic bacterial strains, Staphylococcus aureus (MTCC 2940), Pseudomonas aeruginosa (MTCC 2453), Bacillus subtilis (MTCC 441), Escherichia coli (MTCC 739). Results showed prominent antibacterial impact on these tested bacteria. Lupeol, a pentacyclic triterpenoid was found to be present as a dominant member in Gas chromatography-mass spectrometry (GC-MS) analysis of HMLE. Lupeol is a pentacyclic triterpenoid compound with diverse pharmaceutical applications. This is the maiden report of bioactive compounds from V. squarrosa highlighting their antibacterial, photoprotective and antioxidant activities.

\section{Introduction}

Vernonia squarrosa (D. Don) Less. is an ethnomedicinally important green member of Asteraceae. $V$ squarrosa is a shrub of $70 \mathrm{~cm}$ in height. Stems and branches are striate, glabrous or sparsely hairy. Leaves normally oblong to ovate narrowed at both ends, dentate. Inflorescence capitulum, 3-4 flowers are arranged in axillary or terminal position. It is a little known, unexplored plant found mostly in the Chotanagpur plateau (Adjacent parts of Odisha, West Bengal, Bihar and Chhattisgarh) in India. It has several ethnomedicinal properties, out of which antimicrobial, ascarcidal, luxation is established. However, majority of its medicinal properties is yet to be revealed in details. These plants belong to an evolutionary advanced family Asteraceae which has notable medicinally important members. Naturally, $V$. squarrosa stimulates interest to explore its medicinal attributes. Some of its closely related Vernonia Schreb species those are exhibit distinct bioactivity as anti- inflammatory, antidiabetic, antimicrobial and cytotoxic properties both under in vitro and in vivo (1). Fruits and or seeds of $V$. squarrosa plant were reported to be broadly used as the medicine of Diarrhea (2). The flower head of $V$. squarrosa is mostly used as ascaricidal agents. The mature leaves of the plant were reported as a popular medicine for the treatment of luxation, ulcer, dropsy and wounds (3). Delang already reported that its fruit powder boiled in water is efficient for removing back pain and kidney stone (4). Previous reports are there on antimicrobial efficacy of aqueous and methanolic leaf extracts of the plant on two pathogenic gram negative bacteria, Vibrio cholerae (MTCC 3904) and Shigella dysenteriae (Medical isolates) (5).

Generally, deadly pathogenic microorganisms mainly bacteria, acquire resistance properties against broad spectrum antibiotics due to their random misuses (6). Indiscriminate use of antibiotics not only created resistance issues of target microbes but lack of

(c) Das et al (2021). This is an open-access article distributed under the terms of the Creative Commons Attribution License, which permits unrestricted use, distribution and reproduction in any medium, provided the original author and source are credited (https://creativecommons.org/licenses/by/4.0/).

To cite this article: Das A, Burman S, Chandra G, Bandyopadhyay A. In vitro photoprotective, antioxidant and antibacterial activity of Vernonia squarrosa (D. Don) Less. Plant Science Today. 2021;8(1):331-339. https://doi.org/10.14719/pst.2021.8.2.1037

Plant Science Today, published by Horizon e-Publishing Group, is covered by Scopus, Web of Science, BIOSIS Previews, Clarivate Analytics, etc.

Full list at http://www.plantsciencetoday.online 
newly discovered antibiotics have compounded the problem leading to the serious concern about effectiveness of antimicrobial drugs. In this backdrop, plant derived secondary metabolites offer viable alternative as novel antimicrobial substances. Plant derived secondary metabolites like phenolics, flavonoids, terpenoids, alkaloids have an almost limitless opportunity for searching antimicrobial substances because of their diverse phytoconstituents. It is assumed that more than 250000-500000 plant species are existing with diverge array of phenols, tannins, terpenoids, coumarins, quinones and alkaloids (7). Phenolic acid and flavonoid have the tremendous free radical scavenging ability, antiviral, antimicrobial, antiproliferative and apoptotic activities (8). Flavonoids are the major pigments which can absorb harmful UV radiation strongly (9). The triterpenoid compounds derived from Centella asiatica and Panax notoginseng were also established as potential absorber for UV radiation $(10,11)$.

Since solar radiation consists of electromagnetic wave associated with infrared, visible and UV light and as a consequence direct exposure of ultraviolet radiation through solar light has both positive as well as negative health effect on the human skin. Ultraviolet $B$ spectrum is crucial for Vitamin $D_{3}$ synthesis as it penetrates the human skin to convert 7-dehydrocholestrol into vitamin D (12). UVR (Ultra Violate Radiation) ranges from $100 \mathrm{~nm}$ to $400 \mathrm{~nm}$ and can be divisible into three regions (UV C $100 \mathrm{~nm}-280$ nm, UV B $280 \mathrm{~nm}-315 \mathrm{~nm}$, UV A 315-400 nm). UV A region of the spectra declines strongly when it enters into the earth surface and drops to near zero to 290 $\mathrm{nm}$ (13). Longer exposure to UV light cause photo aging, pigmentation erythrema and oxidative skin damage as DNA molecules readily absorb UV radiation and are also become targets of mutation. $\mathrm{UV} B$ is a shorter length of radiation that can cause melanomas as well as basal and squamous cell carcinomas. The denaturation temperature of type I collagen is decreased when the intensity of UV radiation is increased and triple helical structure is destroyed (14). Exposure to various environmental factors leads free radical formation. The most common free radicals are oxygen or ROS (Reactive Oxygen Species), singlet oxygen and hydroxyl radical $(15,16)$. When they reach electron deficit condition they snatch electron from other molecules mainly DNA, that results DNA damage and mutagenesis. Plants epidermal cell, cuticular wax, flavonoids, phenolic acid, pigments can absorb incoming UV radiation up to $90-99 \%$ (17). In modern lifestyles, sunbathing and holiday habit increases daily exposure of UV light to the skin. Some cosmetic products (Sunscreen, Shampoo) are used to absorb or filter the harmful effect of UV radiations without hampering the normal Vitamin D synthesis process. The photoprotective ability of a sunscreen is measured as a function of their SPF (Sun Protection Factor) value. To protect such oxidative damage, several naturally occurring food and dietary components like flavonoids, phenols, terpenoids and $\beta$ carotene that are well recognized antioxidant as well as anti cancerous agents, are mixed to fortify pharmaceutical formulations of commercial sunscreens. This study was carried out to evaluate the bioactivity of $V$. squarrosa because to the best of the knowledge of the authors, no investigation was executed till now regarding phytochemical value, antioxidant potentiality and photoprotective ability. The authors analysed the potential antibacterial properties of HMLE as well, of two gram positive (Staphylococcus aureus and Bacillus subtilis) and two gram negative (Pseudomonas aeruginosa and Escherichia coli) bacteria.

\section{Materials and Methods}

\section{Plant material collection and authentication}

$V$. squarrosa was collected (September, 2018) from Joypur forest area (23.0540 N \& 87.4345 E) of Bankura district of West Bengal where the plant has been naturally inhabited. The plant sample was identified and authenticated by Dr. Bandana Bhattacharjee and Dr. Avishek Bhattachaejee, Botanical Survey of India. A voucher specimen was deposited in Central National Herbarium of Botanical Survey of India with the reference no. CAL0000031671.

\section{Preparation of Hydro-methanolic leaf extracts}

The fresh leaves were cleaned properly under running tap water and then shade dried in room temperature for 15 days. Then the material was ground to powder with a grinder. For preparation of Hydro-Methanolic Leaf Extract (HMLE), $20 \mathrm{gm}$ of dried powdered leaves was loaded in Soxhlet apparatus containing $200 \mathrm{ml}$ of $80 \%$ methanol maintaining 1:10 ratios. Extraction period was set for $8-10 \mathrm{~h}$ per day with total $90 \mathrm{~h}$ of extraction period by following the standard method with few modifications (18). Thereafter, solvents were collected and excess solvent was evaporated by using rotary evaporator (Buchi type) Residue thus obtained was collected and stored in refrigerator $\left(4{ }^{\circ} \mathrm{C}\right)$ for further use.

\section{Preliminary phytochemical screening}

Preliminary phytochemical analysis was executed using the protocols by (19) for testing the presence of alkaloids, terpenoids, phenols, flavonoids, cardiac glycosides, tannins, saponins, steroids, anthroquinones in HMLE of $V$. squarrosa.

\section{Determination of Total Phenols Content in the leaf extract}

The phenolic content of HMLE was determined spectrophotometrically according to Folin-Ciocalteu method (20) with little modification. A stock solution of $1 \mathrm{mg} / \mathrm{ml}$ extract was prepared by dissolving the HMLE in distilled water. At first $1 \mathrm{ml}$ of sample was taken and mixed with $5 \mathrm{ml}$ of 1:10 Folin-Ciocalteu reagent and shaken gently. After $5 \mathrm{~min} 4 \mathrm{ml}$ of $7.5 \%$ $\mathrm{Na}_{2} \mathrm{CO}_{3}$ solution was added to the mixture. After 60 min of dark incubation the absorbance of reaction mixture was measured at $765 \mathrm{~nm}$ (in triplicate). All values were expressed as $\mu \mathrm{g} / \mathrm{mg}$ Gallic Acid Equivalent (GAE).

\section{Estimation of Total Flavonoids}

Total flavonoid content was determined by spectrophotometrically by using aluminium nitrate (21). At first, $1 \mathrm{ml}$ of extract (HMLE) $(1 \mathrm{mg} / \mathrm{ml})$ was added with $0.1 \mathrm{ml}$ of $10 \%$ aluminium nitrate. Then 
$0.1 \mathrm{ml}$ of $1 \mathrm{M}$ potassium acetate was added to mixture and allowed to stand for $2 \mathrm{~min}$ at room temperature. Then $3.8 \mathrm{ml}$ ethanol was added to the mixture and was kept for $40 \mathrm{~min}$. The absorbance was measured at $415 \mathrm{~nm}$ (in triplicate) and the absorbance value expressed as $\mu \mathrm{g} / \mathrm{mg}$ Quercetin Equivalent (QE).

\section{Estimation of Total Tannin Content}

Vanillin hydrochloride method by Burns 1971 was used to quantify the total tannin content (22). Vanillin hydrochloride reagent (4\%) was prepared by $4 \mathrm{gm}$ vanillin in $100 \mathrm{ml}$ methanol with $8 \%$ hydrochloric acid. This reagent was always freshly prepared just before use. To $5 \mathrm{ml}$ reagent and $1 \mathrm{ml}$ HMLE (1 mg/ml) was mixed and incubated for $20 \mathrm{~min}$ in room temperature. Absorbance was measured at $500 \mathrm{~nm}$ (in triplicate), Keeping vanillin reagent as blank. The absorbance value was expressed as $\mu \mathrm{g} / \mathrm{mg}$ PhloroGlucinol Eqivavalent (PGE).

\section{Estimation of $\beta$ carotene and Lycopene Content}

Amount of $\beta$ carotene and lycopene were determined by following protocol of $(23,24)$ with little modification. In this process, $100 \mathrm{mg}$ of extract was shaken with $10 \mathrm{ml}$ acetone-hexane mixture (4:6) for $1 \mathrm{~min}$ and absorbance was measured at 453, 505 and $663 \mathrm{~nm}$. Consecutively by using the following formula lycopene and $\beta$ carotene contents were computed (in triplicate).

$\beta$-carotene (mg/100 ml): $0.216 \mathrm{~A}_{663}-0.304 \mathrm{~A}_{505}+0.452 \mathrm{~A}_{453}$ Lycopene (mg/100 ml): $-0.0458 \mathrm{~A}_{663}+0.372 \mathrm{~A}_{505}-0.0806 \mathrm{~A}_{453}$

\section{Estimation of Antioxidant Activity by DPPH Method}

DPPH assay: The traditional 2, 2 diphenyl 1picrylhydrazyl free radical method was used in this study (25). A stock solution of $1 \mathrm{mg} / \mathrm{ml}$ of HMLE was prepared and diluted to following concentration viz. $10,20,40,60,80$ and $100 \mu \mathrm{g} / \mathrm{ml}$ and mixed with 0.004 $\%$ methanol solution of DPPH in 1: 1 ratio. Scavenging process of DPPH was carried out at room temperature under dark condition for $30 \mathrm{~min}$. Subsequently, gradual reduction in absorbance of the mixture was recorded at $517 \mathrm{~nm}$ keeping ascorbic acid as standard (in triplicate). $\mathrm{EC}_{50}$ value was taken a potent concentration where $50 \%$ of scavenging of DPPH radicals by HMLE was computed within given incubation period. The scavenging efficacy is express by the following formulae

$$
\% \text { DPPH scavenging }=\left\{\left(\mathrm{A}_{0}-\mathrm{A}_{1}\right) / \mathrm{A}_{0}\right\} \times 100
$$

$\mathrm{A}_{0}=$ Absorbance of control $\mathrm{A}_{1}=$ Absorbance of test sample

\section{ABTS Radical Scavenging Assay}

The ABTS free radical scavenging efficiency was evaluated by following previous method described by (26). Firstly, ABTS free radical was generated by the addition of $7 \mu \mathrm{M}$ ABTS solution with $2.45 \mu \mathrm{M}$ potassium persulfate solution in 1:0.5 proportion and the mixture was incubated in dark for $12-16 \mathrm{hr}$ at room temperature for free radical conversion before use. Then the prepared ABTS $^{*+}$ solutions were diluted with ethanol up to OD of $0.7 \pm 0.05$ at $734 \mathrm{~nm}$ at $30^{\circ} \mathrm{C}$. To evaluate the scavenging efficiency of HMLE, $10 \mu \mathrm{l}$ sample $(100-1000 \mu \mathrm{g} / \mathrm{ml})$ was mixed with $1 \mathrm{ml}$ of diluted ABTS*. The absorbance was measured after 10 min of dark incubation at $734 \mathrm{~nm}$ using ascorbic acid as standard (in triplicate). Scavenging was finally expressed using following formulae.
$\%$ ABTS scavenging $=\left\{\left(\mathrm{A}_{0}-\mathrm{A}_{1}\right) / \mathrm{A}_{0}\right\} \times 100$

$\mathrm{A}_{0}=$ Absorbance of control $\mathrm{A}_{1}=$ Absorbance of test sample

\section{Reducing Power Assay}

Ferric ion reducing power of HMLE of $V$. squarrosa was determined by following the method of Oyaizu et al. 1986 with few changes (27). A stock solution of 1 $\mathrm{mg} / \mathrm{ml}$ of HMLE was prepared and diluted with methanol following concentration viz. 10, 20, 40, 60, $80,100 \mu \mathrm{g} / \mathrm{ml}$. To $1 \mathrm{ml}$ each of diluted extracts, $1 \mathrm{ml}$ of $0.2 \mathrm{M}$ phosphate buffer $\mathrm{pH} 6.6$ was added in separate tubes, to which $1 \mathrm{ml}$ of $1 \%(\mathrm{w} / \mathrm{v})$ potassium ferricyanide was further mixed to each of the reaction mixture and was then incubated for $20 \mathrm{~min}$ at $50^{\circ} \mathrm{C}$. Then $10 \% 1 \mathrm{ml}$ Trichloroacetic acids (TCA) were added in each reaction mixtures. After that, 2 $\mathrm{ml}$ of each reaction mixture was diluted with $2 \mathrm{ml}$ of distilled water followed by addition of $0.4 \mathrm{ml}$ ferric chloride solution $(0.1 \% \quad \mathrm{w} / \mathrm{v})$. Absorbance was measured at $700 \mathrm{~nm}$. Ascorbic acid was used as internal standard.

\section{In Vitro Assessment of Sun Protection Factor of HMLE}

SPF properties of the HMLE were examined as per the standard method (28). A stock solution of $1 \mathrm{mg} / \mathrm{ml}$ of crude leaf extract was prepared and diluted to following concentration viz. 50, 100, 200, 400, 600, 800, $1000 \mu \mathrm{g} / \mathrm{ml}$. Absorption spectra of sample solution were obtained in the range of $200 \mathrm{~nm}$ to 400 $\mathrm{nm}$ taking distilled water as blank. The absorption data in triplicate were recorded by UV-Vis spectrophotometer (Shimadzu UV-1800) at every 5 $\mathrm{nm}$ interval from 290 to $320 \mathrm{~nm}$. SPF value was expressed as a function of erythemal effect spectrum as per following formulae.

$$
\mathrm{SPF}=\mathrm{CF} \times{ }^{320} \Sigma_{290} \mathrm{EE}(\lambda) \times \mathrm{I}(\lambda) \times \operatorname{Abs}(\lambda)
$$

$\operatorname{EE}(\lambda)=$ erythemal effect spectrum. $\operatorname{Abs}(\lambda)=$ absorbance of sunscreen product. $\mathrm{CF}=$ correction factor (10). The values of $\mathrm{EE} \times$ I remain constant (29).

\begin{tabular}{|c|c|}
\hline $\begin{array}{c}\text { Values of EE }(\lambda) \text { x I at } \\
\text { different wavelength }\end{array}$ & Value of EE X I \\
\hline 290 & 0.0150 \\
\hline 295 & 0.0817 \\
\hline 300 & 0.2874 \\
\hline 305 & 0.3278 \\
\hline 310 & 0.1864 \\
\hline 315 & 0.0837 \\
\hline 320 & 0.0180 \\
\hline
\end{tabular}

\section{Determination of Antimicrobial Potentiality}

Test Microorganism Antibacterial assay was conducted by agar well diffusion method (30) on four human-pathogenic bacterial strains Staphylococcus aureus MTCC 2940, Bacillus subtilis MTCC 441, Escherichia coli MTCC 739 and Pseudomonas aeruginosa MTCC 2453. Inoculum of each tested bacteria was prepared in MüellerHinton broth and turbidity was adjusted to 0.5 Mcfarland turbidity standards. Uniform wells of 6 $\mathrm{mm}$ in diameter were made on solidified agar. Each well was filled with $50 \mu \mathrm{l}$ of HMLE (5000 $\mu \mathrm{g} / \mathrm{ml})$. Tetracycline $(30 \mu \mathrm{g} / \mathrm{ml})$ was kept as positive control. Plates (sets in triplicate) were then 
incubated overnight at $37{ }^{\circ} \mathrm{C}$. Wells filled with sterile distilled water was taken as the negative control. Antibacterial activity of the extract (HMLE) was determined by assessing the diameter of the clear zones around each well.

\section{Determination of Minimum Inhibitory Concentration (MIC)}

MIC is the lowest concentration of antibacterial agent that inhibits the growth of bacteria after 18-24 hr incubation. MIC of the tested extracts was evaluated by serial broth dilution technique $(31,32)$ in which overnight cultures of test bacterial strains grown in nutrient broth cultures were diluted 100 folds. Different concentrations (100-1000 $\mu \mathrm{g} / \mathrm{ml})$ of HMLE were prepared in distilled water and were added to each test tube containing the bacterial cultures to evaluate the MIC of leaf extract (HMLE) against all the strains. Test tubes were then incubated at $37{ }^{\circ} \mathrm{C}$ for about $24 \mathrm{hrs}$. Test bacteria inoculated inoculums were kept as negative control for each test batch. MIC of Tetracycline (positive control) was also assessed. The lowest concentration i.e. the highest dilution of the extract (HMLE) that produced no visible bacterial growth i.e. no turbidity in comparison to the relative turbidity (OD) of the positive control was considered as MIC value.

\section{FT-IR Analysis}

FT-IR (Fourier Transform Infrared Spectroscopy) is a powerful approach to identify the type of chemical bond (functional group) present in the compounds. The Hydro-Methanolic Leaf Extract (HMLE) of the plant mixed with $\mathrm{KBr}$ salt using a hydraulic press and compressed into thin tablets and IR spectra and peaks were recorded on a FT-IR (Jasco, FT/IR- 4700), with a scan range from 400 to $4500 \mathrm{~cm}^{-1}$. Each analysis was done two times for confirmation. FT-IR spectroscopy reveals various functional groups present in the sample.

\section{GC-MS Analysis}

The purified fraction (filter sterilize by $0.22 \mu$ syringe filter) was subjected to GC-MS analysis using TRACE GC Ultra method coupled with POLARIQ MS (MFd-thermo scientific with ion trap technology). Stationary phase used was DBMS column. GC-MS analyses were done with ionization energy of $70 \mathrm{eV}$. The initial oven temperature was programmed to $40{ }^{\circ} \mathrm{C}$ for $2 \mathrm{~min}$, and was gradually increased by 3 ramps, first at a rate of $3{ }^{\circ} \mathrm{C} / \mathrm{min}$ (hold time $1 \mathrm{~min}$ ) to $130{ }^{\circ} \mathrm{C}$, second at $2^{\circ} \mathrm{C} / \mathrm{min}$ (hold time $2 \mathrm{~min}$ ) to $180{ }^{\circ} \mathrm{C}$ and $3^{\text {rd }}$ at a rate of $3^{\circ} \mathrm{C} / \mathrm{min}$ until reaching the final temperature of $280{ }^{\circ} \mathrm{C}$ and holding for $15 \mathrm{~min}$. The total run time was $60 \mathrm{~min}$. Helium $(\mathrm{He})$ was the carrier gas used at a linear flow-rate of $1.0 \mathrm{ml} / \mathrm{min}$ $(99.999 \%)$. The scan range was at a rate of 0.7 scan/s from 50-900 m/z. Purity of each GC peak was checked by taking MS (m/z ratio) at various parts of each peak. All compounds were identified via mass spectral database search of National Institute of Standard Technologies (NIST, 2014) by the matching of MS data.

\section{Statistical Analysis}

The values were analyzed by using MS Excel 2007 and presented as mean \pm SD of three replicates.

\section{Results and Discussion}

Qualitative and Quantitative Estimation of Secondary Metabolites of HMLE

Aqueous extraction is generally used for pharmacological screening but, since the aromatic organic compounds are generally active on microbial growth and behave as free radical scavengers, they are often dissolved in polar organic solvents like methanol or ethanol (33). Hydro-Methanol Leaf Extract (HMLE) was used for the study of antioxidant, photoprotective and antimicrobial and also for presence of bioactive organic compounds. Preliminary phytochemical investigations revealed the presence of phenols, flavonoids, tannins, cardiac glycosides, alkaloids (Table 1). The major chemical component found to be phenols $(272.44 \pm 9.78 \mu \mathrm{g} / \mathrm{mg})$ as Gallic Acid Equivalent (GAE), followed by flavonoids $(77.50 \pm 1.41 \mu \mathrm{g} / \mathrm{mg})$ and tannins $(27.97 \pm$ $3.15 \mu \mathrm{g} / \mathrm{mg}$ ). Whereas small quantity of $\beta$-carotene (53 $\pm 0.0009 \mu \mathrm{g} / \mathrm{mg})$ and Lycopene $(28 \pm 0.003 \mu \mathrm{g} / \mathrm{mg})$ were also detected (Table 2).

Table 1. Qualitaive phytochemical screening

\begin{tabular}{lc}
\hline Phytochemicals & HMLE \\
\hline Alkaloid & $+\mathrm{Ve}$ \\
\hline Terpenoid & $+\mathrm{Ve}$ \\
\hline Phenols & $+\mathrm{Ve}$ \\
\hline Flavonoids & $+\mathrm{Ve}$ \\
\hline Cardiac glycosides & $+\mathrm{Ve}$ \\
\hline Steroides & $-\mathrm{Ve}$ \\
\hline Saponins & $+\mathrm{Ve}$ \\
\hline Anthraquinones & $-\mathrm{Ve}$
\end{tabular}

Table 2. Quantitative value of secondary metabolites

\begin{tabular}{lc}
\hline Parameters & \multicolumn{1}{l}{ HMLE } \\
\hline Phenol $(\mu \mathrm{g}$ GAE/mg of extract) & $272.44 \pm 9.78$ \\
\hline Flavonoid $(\mu \mathrm{g} \mathrm{QE} / \mathrm{mg}$ of extract) & $77.50 \pm 1.41$ \\
\hline Tannin $(\mu \mathrm{g} \mathrm{PG} / \mathrm{mg}$ of extract) & $27.97 \pm 3.15$ \\
\hline$\beta$-carotene $(\mu \mathrm{g} / \mathrm{mg}$ of extract) & $53 \pm 0.0009$ \\
\hline Lycopene $(\mu \mathrm{g} / \mathrm{mg}$ of extract & $28 \pm 0.003$ \\
\hline
\end{tabular}

\section{Antioxidant Activity of Hydro-Methanol Leaf Extract (HMLE)}

The stable free radical, DPPH (2, 2-diphenyl-1picrylhydrazyl) when dissolved in methanol it produces violate color which contains $\mathrm{N}_{2}$-centered free radical. The violet color of the solution turns yellow when the free radical was scavenged by the antioxidants agents. Hydro-Methanol Leaf Extract

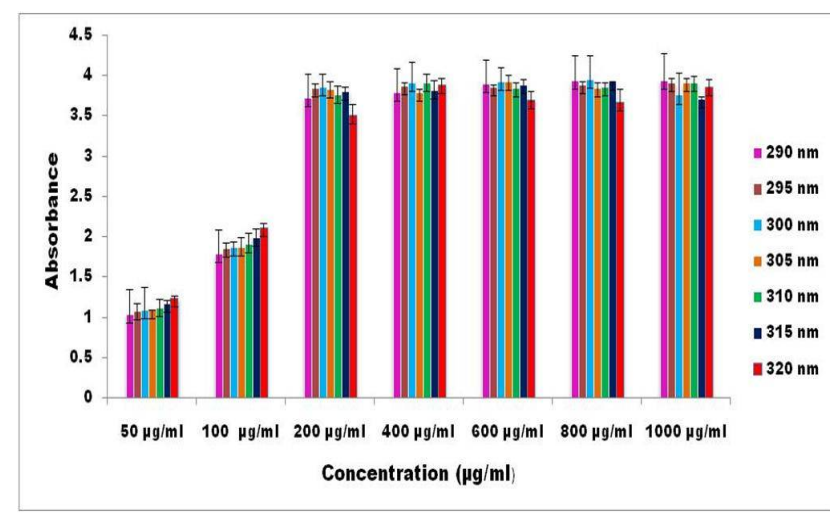

Fig. 2. Effect of HMLE concentration on the UV absorption capacity. 
(HMLE) of $V$. squarrosa exhibited significant free radical quenching ability at the rate of $32.16,51.12$, 92.26, 95.76, 92.36 and $96.50 \%$ at 10, 20, 40, 60, 80 and $100 \mu \mathrm{g} / \mathrm{ml}$ respectively (Fig. 1 A). Previously, (supplementary material Table S1-S7), which is concentration dependent too. The absorbance of the extract did not alter even when the concentration of extract was raised beyond $200 \mu \mathrm{g} / \mathrm{ml}$. Consequently
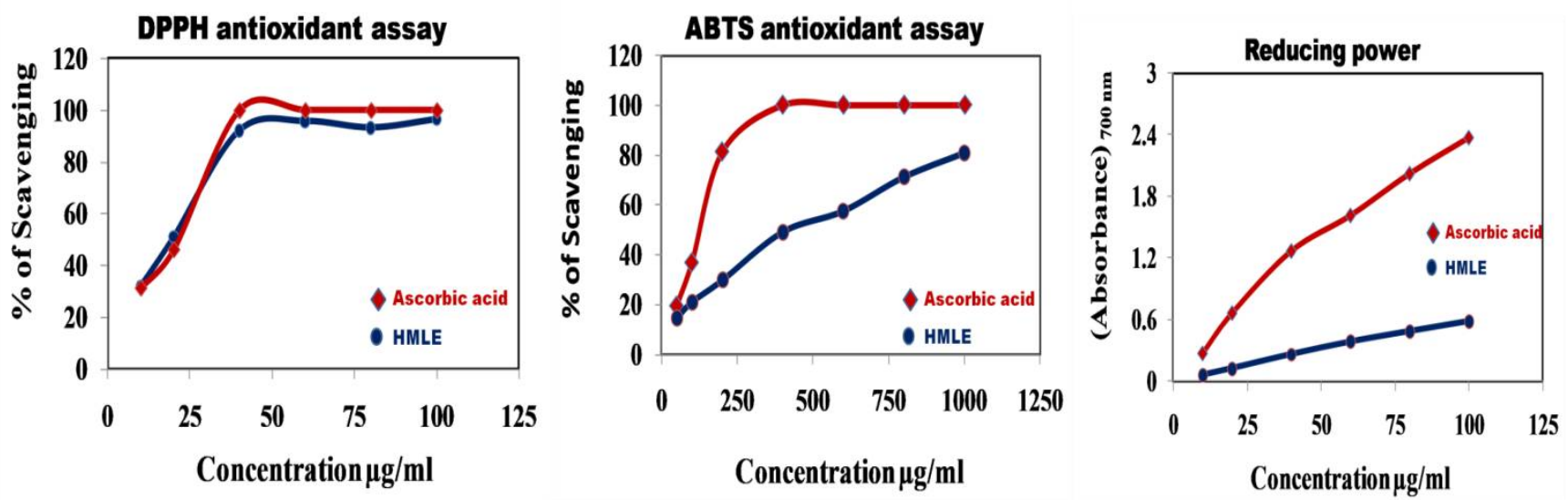

Fig. 1. Antioxidant activity of crude HMLE of $V$. squarrosa A) DPPH free radical scavenging ability B) ABTS free radical scavenging potentiality C) Reducing power of HMLE.

reported that methanolic (90\%) leaf extract of Vernonia cinerea demonstrated DPPH free radical scavenging potentiality with $56 \pm 6.92 \mathrm{EC}_{50}$ Value (34). Whereas $V$. squarrosa (HMLE) exhibits far better antioxidant capabilities with $\mathrm{EC}_{50}$ value of $11.63 \pm 2.60$ $\mu \mathrm{g} / \mathrm{ml}$ (Table 3$)$. The free radical cation of ABTS $(2,2 '-$ azino-bis (3-ethylbenzothiazoline-6-sulfonic acid) was generated after addition of potassium persulfate which leads to a blue coloration. The scavenging percentage of ABTS free radical was found to be

Table 3. In vitro antioxidant ability of HMLE of $V$. squarrosa

\begin{tabular}{lcc}
\hline Antioxidant parameters & $\begin{array}{c}\mathbf{E C}_{\mathbf{5 0}} \text { value of HMLE } \\
(\boldsymbol{\mu} \mathbf{g} / \mathbf{m l})\end{array}$ & $\begin{array}{c}\mathbf{E C}_{50} \text { value of } \\
\text { Ascorbic acid } \\
(\boldsymbol{\mu g} / \mathbf{m l})\end{array}$ \\
\hline $\begin{array}{l}\text { Scavenging ability of DPPH } \\
\text { free radical }\end{array}$ & $11.63 \pm 2.60$ & $13.33 \pm 0.88$ \\
\hline $\begin{array}{l}\text { Scavenging ability of ABTS } \\
\text { free radical }\end{array}$ & $497.85 \pm 12.38$ & $86.18 \pm 0.99$ \\
\hline Reducing power & $96.53 \pm 0.83$ & $14.93 \pm 0.98$ \\
\hline
\end{tabular}

dependent on concentration of HMLE with a scavenging ability of $25.07,31.40,45.34,58.10,69.41$ and $80.24 \%$ at $100,200,400,600,800$, and $1000 \mu \mathrm{g} / \mathrm{ml}$ concentration with $\mathrm{EC}_{50}$ value of $497.85 \pm 12.38 \mu \mathrm{g} / \mathrm{ml}$ (Fig. 1 B, Table 3). Similarly, assay for reducing power of HMLE was carried out to evaluate electron donating capabilities of the HMLE for the reduction of potassium ferricyanide, which was also found to be concentration dependent. The $\mathrm{EC}_{50}$ value for the conversion of $\mathrm{Fe}^{3+} /$ ferricyanide to the ferrous form $\left(\mathrm{Fe}^{2+}\right)$ was recorded as $96.53 \pm 0.83 \mu \mathrm{g} / \mathrm{ml}$ (Fig. $1 \mathrm{C}$, Table 3).

\section{Estimation of Sun Protection Factors of Hydro- Methanol Leaf Extract (HMLE)}

The SPF values were evaluated by the standard method (28). The SPF value of HMLF of $V$. squarrosa was determined by taking absorbance at $5 \mathrm{~nm}$ interval from $290 \mathrm{~nm}$ to $320 \mathrm{~nm}$ on different concentrations viz. 50, 100, 200, 400, 600, 800 and $1000 \mu \mathrm{g} / \mathrm{ml}$ (Fig. 2). The evaluated photoprotective activity (SPF value) recorded from 11.04-38.87
SPF value did not fluctuate too much and it stuck around a value of 38 . The SPF value above 6 is appropriate for sunscreen formulation according to the Brazilian law, RDC 30 from June 1, $2012(35,36)$. According to SPF reference scale, sunscreen products can be classified as low protection $(\mathrm{SPF}<12)$, moderate (12-30) which can protect around 93\% from UV B rays, SPF (30-50) high protection which can block harmful UV B radiation up to $97 \%(37,38)$ (Fig. 3 , Table 4). There are reports on the essential oil of Calendula officinalis (Asteraceae) possessed good photoprotective ability (SPF $14.84 \pm 0.16$ ) (39). Crude Rosa kordesii extract (SPF $20.15 \pm$ 0.05) showing significant amount of UV ray blocking potentiality (40). The results of Hydro-Methanol Leaf Extract

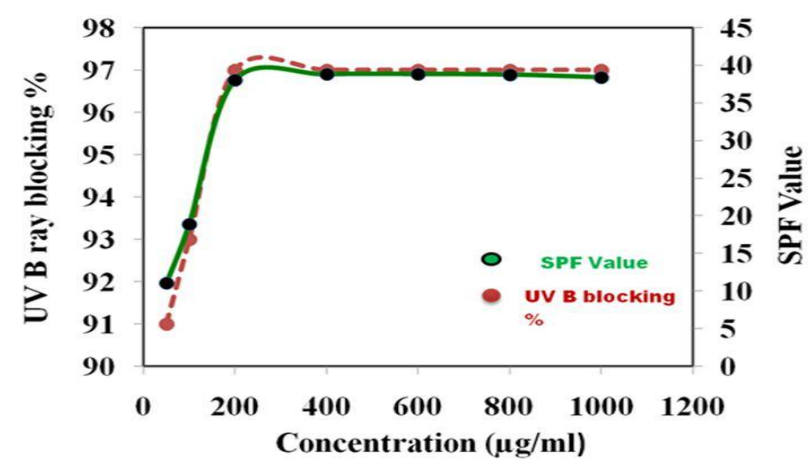

Fig. 3. Concentration dependent SPF value with its protection levels and UV B light blocking percentage.

Table 4. Concentration dependent SPF value with its protection levels

\begin{tabular}{ccc}
\hline $\begin{array}{c}\text { Concentration } \\
(\boldsymbol{\mu g} / \mathbf{m l})\end{array}$ & SPF value & $\begin{array}{c}\text { Protection level (UV B } \\
\text { blocking) }\end{array}$ \\
\hline 50 & $11.04 \pm 3.04$ & Low protection \\
\hline 100 & $18.90 \pm 0.54$ & Moderate \\
\hline 200 & $38.08 \pm 1.60$ & High protection \\
\hline 400 & $38.47 \pm 0.62$ & High protection \\
\hline 600 & $38.87 \pm 0.28$ & High protection \\
\hline 800 & $38.80 \pm 0.39$ & High protection \\
\hline 1000 & $38.44 \pm 0.70$ & High protection \\
\hline
\end{tabular}


(HMLE) clearly indicate that $V$. squarrosa possesses amazing photoprotective ability with SPF 38 at minimum concentration of $200 \mu \mathrm{g} / \mathrm{ml}$ which appears to be significant finding. It's not difficult to envisage that such plant extract would be commercially sourced to extract such high potency SPF compounds to develop next generation sunscreens.

\section{Antibactertial Activity of Hydro-Methanol Leaf Extract (HMLE)}

Plants are endowed with significant antibacterial ability and are sourced to cure ailments to human civilization. Presence of several phytoconstituents is imparting bioactive efficacies of plant extracts. In the present study antibacterial effect of hydro methanolic leaf extract of $V$. squarrosa has been assessed (Table 5). The HMLE is effective against both gram positive and gram negative pathogenic strains and highest inhibition zone $(20.33 \pm 0.33 \mathrm{~mm})$ was recorded in $B$. subtilis (MTCC 441) followed by $P$. aeruginosa (MTCC 2453), E. coli (MTCC 739) and S. aureus (MTCC 2940). Minimum inhibitory concentration ranged between 125-250 $\mu \mathrm{g} / \mathrm{ml}$ (Table

Table 5. Antibactertial activity of HMLE of $V$. squarrosa and its minimum inhibitory concentration

\begin{tabular}{|c|c|c|c|c|}
\hline $\begin{array}{l}\text { Bacterial } \\
\text { strains }\end{array}$ & $\begin{array}{c}\text { Zone of } \\
\text { Inhibition } \\
(\mathrm{mm}) \text { of } \\
\text { HMLF (5000 } \\
\mu \mathrm{g} / \mathrm{ml})\end{array}$ & $\begin{array}{c}\text { Zone of } \\
\text { Inhibition } \\
\text { (mm) of } \\
\text { Tetracyclin } \\
\text { e(30 } \mu \mathrm{g} / \mathrm{ml}\end{array}$ & $\begin{array}{c}\text { MIC } \\
(\mu \mathrm{g} / \mathrm{ml}) \text { of } \\
\text { HMLE }\end{array}$ & $\begin{array}{c}\text { MIC } \\
\text { ( } \mu \mathrm{g} / \mathrm{ml}) \text { of } \\
\text { Tetracycli } \\
\text { ne }\end{array}$ \\
\hline $\begin{array}{l}\text { Staphylococcus } \\
\text { aureus (MTCC } \\
\text { 2940) } \\
\end{array}$ & $14.33 \pm 0.33$ & $21.00 \pm 0.33$ & $250.00 \pm 0.67$ & $2.00 \pm 0.88$ \\
\hline $\begin{array}{l}\text { Pseudomonas } \\
\text { aeruginosa } \\
\text { (MTCC 2453) }\end{array}$ & $18.67 \pm 0.88$ & $16.00 \pm 0.67$ & $125.00 \pm 0.33$ & $16.00 \pm 0.58$ \\
\hline $\begin{array}{l}\text { Bacillus subtilis } \\
\text { (MTCC 441) }\end{array}$ & $20.33 \pm 0.33$ & $15.00 \pm 0.00$ & $125.00 \pm 0.00$ & $2.00 \pm 0.00$ \\
\hline $\begin{array}{l}\text { Escherichia coli } \\
\text { (MTCC 739) }\end{array}$ & $15.00 \pm 0.00$ & $16.00 \pm 0.33$ & $250.00 \pm 0.00$ & $64.00 \pm 0.33$ \\
\hline
\end{tabular}

5). Thus the results of MICs clearly indicate that MIC values of $V$. squarrosa were significantly lesser compared earlier reports of similar plant Vernonia amygdalina which had MIC values ranged between 12.5 and $50 \mathrm{mg} / \mathrm{ml}$ (41). When tested with standard broad spectrum antibiotic Tetracycline (30 $\mu \mathrm{g} / \mathrm{ml})$, results indicated that HMLE was more effective than Tetracycline in terms of the size of inhibition zone. These findings signify that this plant has potential source of antibacterial agents.

\section{FTIR Analysis Leaf Extract (HMLE)}

FTIR analysis (Fig. 4) of the HMLF revealed broad band at $3292.86 \mathrm{~cm}^{-1}$, implied to the hydrogen bonded $\mathrm{O}-\mathrm{H}$ stretching. Another two peaks at around $2923 \mathrm{~cm}^{-1}$ and $2853 \mathrm{~cm}^{-1}$ indicated the existence of aliphatic $\mathrm{C}-\mathrm{H}$ stretching of methylene $(42,43)$. The peak at $1593.88 \mathrm{~cm}^{-1}$ assigning the $\mathrm{C}=\mathrm{N}$ and $\mathrm{C}-\mathrm{N}-\mathrm{H}$ stretching (Amide II) whereas band at $1032.69 \mathrm{~cm}^{-1}$ confirming the presence of alcoholic $\mathrm{OH}$ group (44).

\section{GC-MS Analysis of Leaf Extract (HMLE)}

GC MS is a powerful technique to identify and quantify volatile compound like terpenoids, ester. In our study, HMLE exhibited eight peaks on GC MS chromatogram (Fig. 5). Those peaks denote the existence of medicinally important bioactive

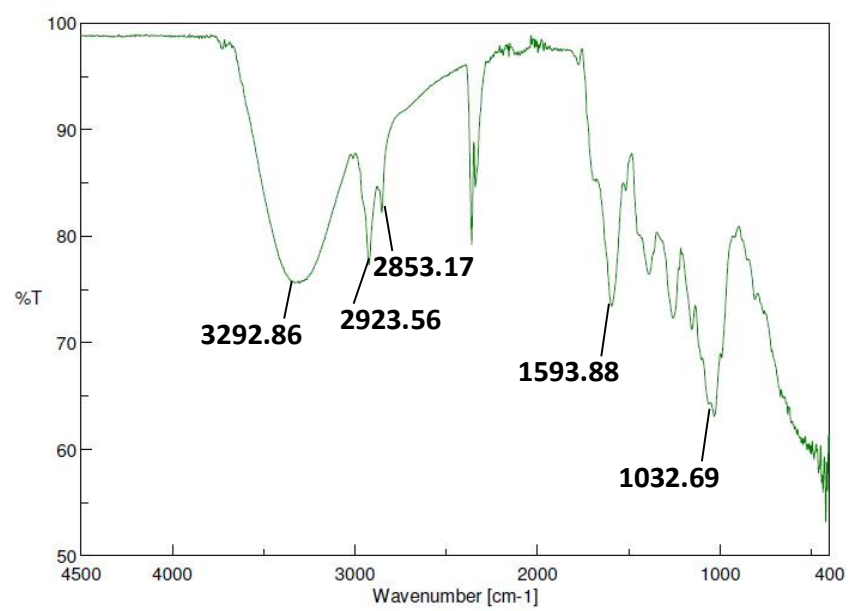

Fig. 4. FTIR spectra of HMLE of $V$. squarrosa.

compounds. The molecular structures of those identified compounds are listed in the (Table 6 and supplementary material Fig. S1-S8). Among eight compounds, 2-Thio-2,4-oxazolidinedione $\left(\mathrm{C}_{3} \mathrm{H}_{3} \mathrm{NO}_{2} \mathrm{~S}\right.$, RT 5.77) and its derivative are actively used for the synthesis of anti-cancer agents (45). Benzaldehyde, 3(2,4,6-trichlorophenoxy methyl-4-methoxy $\left(\mathrm{C}_{3} \mathrm{H}_{3} \mathrm{NO}_{2} \mathrm{~S}\right.$,

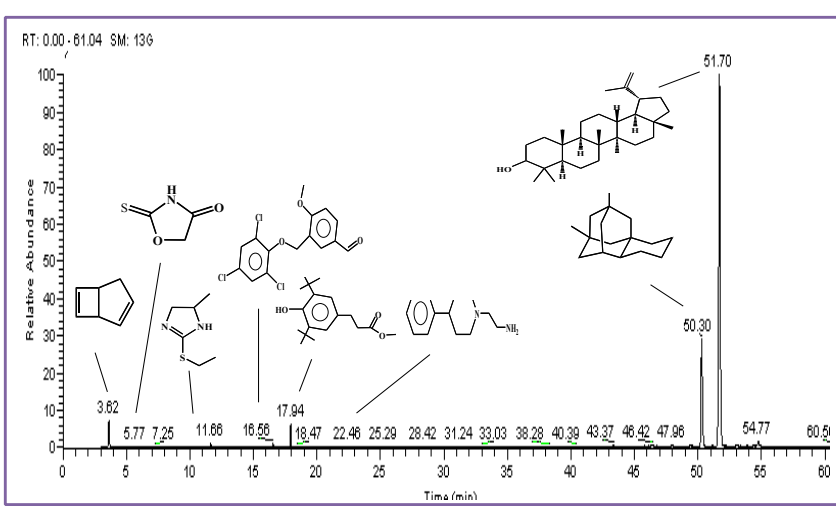

Fig. 5. GC MS chromatogram of hydro-methanolic leaf extracts (HMLE) of $V$. squarrosa.

RT 16.56) was reported as an anti-microfouling agent (46). Benzenepropanoic acid, 3, 5-bis (1, 1dimethylethyl)-4-hydroxy-methyl ester $\left(\mathrm{C}_{18} \mathrm{H}_{28} \mathrm{O}_{3}\right.$ RT 17.94) is a well established anti-oxidant agent (47). Lupeol $\left(\mathrm{C}_{30} \mathrm{H}_{50} \mathrm{O}\right.$, RT 50.70) with $61.77 \%$ peak area is the major compound identified from $V$. squarrosa. Lupeol possesses diverse pharmacological activities under in vitro and in vivo conditions such as antiinflammation, anti-cancer, anti-arthritis, antimicrobial, anti-angiogenic, cardiovascular disease and it is also used as a cholesterol lowering agent (48). Antioxidant properties of lupeol had been extensively reviewed (49). Moreover, Tchimene et al. in 2016 revealed strong antioxidant activity of lupeol isolated from methanolic leaf extract of Crateva adansonii Oliv. (Capparidaceae) (50). Antibacterial activity of lupeol has also been established from Mesua ferrea stems (51). In our study, we also found potential photoprotective, antibacterial and antioxidant activities of the leaf extract $V$. squarrosa and from these findings an inference can be made that the presence of lupeol and other compounds may responsible for these biological properties of $V$. 
Table 6. Chemical compounds of HMLF identified by GC MS

\begin{tabular}{|c|c|c|c|c|}
\hline Compound & RT & $\begin{array}{c}\text { \% peak } \\
\text { Area }\end{array}$ & $\begin{array}{c}\text { Mol. } \\
\text { weight }\end{array}$ & $\begin{array}{l}\text { Chemical } \\
\text { formula }\end{array}$ \\
\hline Bicyclo $[3,2,0]$ hepta-2,6-diene & 3.62 & 2.65 & 92 & $\mathrm{C}_{7} \mathrm{H}_{8}$ \\
\hline 2-Thio-2,4-oxazolidinedione & 5.77 & 0.25 & 177 & $\mathrm{C}_{3} \mathrm{H}_{3} \mathrm{NO}_{2} \mathrm{~S}$ \\
\hline 2-Ethylthio-5-Methylimidazoline & 11.66 & 0.32 & 144 & $\mathrm{C}_{6} \mathrm{H}_{12} \mathrm{~N}_{2} \mathrm{~S}$ \\
\hline Benzaldehyde,3-(2,4,6-trichlorophenoxy methyl-4-methoxy & 16.56 & 0.3 & 344 & $\mathrm{C}_{3} \mathrm{H}_{3} \mathrm{NO}_{2} \mathrm{~S}$ \\
\hline Benzenepropanoic acid,3,5-bis(1,1-dimethylethyl)-4-hydroxy-methyl ester & 17.94 & 1.95 & 292 & $\mathrm{C}_{18} \mathrm{H}_{28} \mathrm{O}_{3}$ \\
\hline 2-(4-phenyl-piperidine-1-yl)-ethylamine & 22.46 & 0.15 & 204 & $\mathrm{C}_{13} \mathrm{H}_{20} \mathrm{~N}_{2}$ \\
\hline 9,11-Dimethyletracyclo $[7,3,1,0(2,7), 1(7,11)]$ tetradecane & 50.30 & 16.15 & 218 & $\mathrm{C}_{16} \mathrm{H}_{26}$ \\
\hline Lupeol & 50.70 & 61.77 & 426 & $\mathrm{C}_{30} \mathrm{H}_{50} \mathrm{O}$ \\
\hline
\end{tabular}

squarrosa plant extract. This is the first time we report the exploration of bioactive compounds from Hydro Methanolic Leaf Extract of $V$. squarrosa, particularly for their photoprotective, antibacterial and antioxidant activities.

\section{Conclusion}

This study was carried out to evaluate the bioactivity of $V$. squarrosa. To the best of our knowledge, no investigation has been carried out till now regarding bioactive compounds, antioxidant potential and photoprotective property of this plant. The preliminary investigation revealed that HMLE exhibits relatively good potential in DPPH, ABTS radical scavenging and reducing power mostly due to high phenol, flavonoid and terpenoid content. The HMLE exhibits amazing photoprotective ability and antimicrobial properties against two gram positive (Staphylococcus aureus, Bacillus subtilis) and two gram negative (Pseudomonas aeruginosa, Escherichia coli) bacteria tested. The presence of lupeol (pentacyclic triterpenoid) was identified in significant quantity by GC MS analysis which is a momentous finding of our study. The above findings underline the significance of $V$. squarrosa as storehouse of a variety of herbal medicines.

\section{Acknowledgements}

The authors gratefully acknowledge the Council of Scientific and Industrial Research (CSIR), New Delhi, India, for providing financial support in the form of Junior Research Fellowship (09/025(0250)/2018-EMRI). The authors also thankfully acknowledge The University of Burdwan for infrastructural facilities. The authors wish to thanks Dr. Bandana Bhattacharjee \& Dr. Avishek Bhattachaejee of Botanical Survey of India (CNH) for identification of Vernonia squarrosa. The authors gratefully acknowledge Bose Institute Kolkata for GC-MS facility.

\section{Authors' contributions}

AD, SB carried out all the experiments. AD, SB wrote and formatted the manuscripts. $A B$ hypothesized and designed all above the experiments. AB, GC read and made critical changes.

\section{Conflict of interests}

The authors have no conflict of interest to disclose.

\section{Supplementary files}

Table S1. Table showing the Determination of SPF Value at $50 \mu \mathrm{g} / \mathrm{ml}$ extracts (HMLE) concentration

Table S2. Table showing the Determination of SPF Value at $100 \mu \mathrm{g} / \mathrm{ml}$ extracts (HMLE) concentration

Table S3. Table showing the Determination of SPF Value at $200 \mu \mathrm{g} / \mathrm{ml}$ extracts (HMLE) concentration

Table S4. Table showing the Determination of SPF Value at $400 \mu \mathrm{g} / \mathrm{ml}$ extracts (HMLE) concentration

Table S5. Table showing the Determination of SPF Value at $600 \mu \mathrm{g} / \mathrm{ml}$ extracts (HMLE) concentration

Table S6. Table showing the Determination of SPF Value at $800 \mu \mathrm{g} / \mathrm{ml}$ extracts (HMLE) concentration

Table S7. Table showing the Determination of SPF Value at $1000 \mu \mathrm{g} / \mathrm{ml}$ extracts (HMLE) concentration

Fig. S1. The mass spectrum of Bicyclo [3,2,0] hepta2,6-diene, RT 3.62

Fig. S2. The mass spectrum of 2-Thio-2,4oxazolidinedione, RT 5.77

Fig. S3. The mass spectrum of 2-Ethylthio-5Methylimidazoline, RT 11.66

Fig. S4. The mass spectrum of Benzaldehyde,3-(2,4,6trichlorophenoxy methyl-4-methoxy, RT 16.56

Fig. S5. The mass spectrum of Benzaldehyde,3-(2,4,6trichlorophenoxy methyl-4-methoxy, RT 17.94

Fig. S6. The mass spectrum of 2-(4-phenyl-piperidine1-yl)-ethylamine, RT 22.46

Fig. S7. The mass spectrum of 9,11-Dimethyletracyclo $[7,3,1,0(2,7), 1(7,11)]$ tetradecane, RT 50.30

Fig. S8. The mass spectrum of Lupeol, RT 50.70

\section{References}

1. Toyang NJ, Verpoorte R. A review of the medicinal potentials of plants of the genus Vernonia (Asteraceae). J. Ethnopharmacol. 2013;146:681-723. https://doi.org/10.1016/j.jep.2013.01.040

2. Quattorocchi U. CRC World dictionary of medicinal and poisonous plants, CRC press; 2016. p. 3892.

3. Jaipurian MK. Herbs of tribal land Jharkhand, India, Scientific publishers; 2017. p. 345.

4. Delang CO.. The role of medicinal plants in the provision of healthcare in lao. PDR Journal of Medicinal Plants. 2007;1(3);50-59.

5. Panda SK, Mohanta YK, Padhi L, Park YH, Mohanta TK, Bae H. Large scale screening of ethnomedicinal plants for identification of potential antibacterial compounds. Molecules. https://dx.doi.org/10.3390\%2Fmolecules21030293

6. Coates $\mathrm{A}, \mathrm{Hu} \mathrm{Y}$, Bax R, Page $\mathrm{C}$. The future challenges facing the development of new antimicrobial drugs. Nat Rev Drug Discov. 2002;1(11):895-10. https://doi.org/10.1038/nrd940 
7. Cowan MM. Plant products as antimicrobial agents. Clin Microbiol Rev. 1999;12:564-82.

8. Plazonić A, Bucar F, Maleš Ž, Mornar A, Nigović B, Kujundži N. Identification and quantification of flavonoids and phenolic acids in Burr Parsley (Caucalis platycarpos L.), using highperformance liquid chromatography with diode array detection and electrospray ionization mass spectrometry. Molecules.

https://dx.doi.org/10.3390\%2Fmolecules14072466

2009;14:2466-90

9. Robberecht R, Caldwell MM. Leaf epidermal transmittance of ultraviolet radiation and its implications for plant sensitivity to ultraviolet-radiation induced injury. Oecologia (Berl.) 1978;32: 277-87.

10. Sene G, Loiseau A, Meybeck A, Yang CR. The use of ginsenoside and a plant extract containing ginsenoside in a cosmetic or pharmaceutical or in a food supplement for the protection of skin against sunlight or UV radiation. 2009;US Patent 2009016923.

11. Hashim P, Sidek H, Helan MHM, Sabery A, Palanisamy UD, Ilham M. Triterpene composition and bioactivities of Centella asiatica. Molecules. https://doi.org/10.3390/molecules16021310

12. Nair R, Maseeh A. Vitamin D: The "sunshine" vitamin. J pharmacol Pharmacother. https://doi.org/10.4103/0976-500x.95506

13. Robberecht R. Environmental photobiology, Smith KC, editor The Science of Photobiology. Plenum Press, New York; 1989. p.135-54.

14. Majewski AJ, Sanzari M, Cui HL, Torzilli P. Effects of ultraviolet radiation on the type-I collagen protein triple helical structure: A method for measuring structural changes through optical activity. Phys Rev. 2002;65:031920. https://doi.org/10.1103/PhysRevE.65.031920

15. Nilsson R, Merkel PB, Kearns DR. Unambiguous evidence for the participation of singlet oxygen (1) in photodynamic oxidation of amino acid. Photochem Photobiol. 1972;16:117724. https://doi.org/10.1111/j.1751-1097.1972.tb07343.x

16. Foote CS.. Free radicals in biology II. In: Pryor W, editor. Academic Press., New York; 1976. p. 85-133.

17. Stapleton AE, Walbot V. Flavonoids can protect maize DNA from the induction of ultraviolet radiation damage. Plant Physiol. 1994;105:881-89. https://doi.org/10.1104/pp.105.3.881

18. Burman S, Bhattacharya K, Mukherjee D, Chandra G. Antibacterial efficacy of leaf extracts of Combretum album Pers. against some pathogenic bacteria. BMC Complement. Altern. Med. 2108;18:213.

19. Harborne JB. Phytochemical methods, 2nd ed, Chapman \& Hall, London, 1984;85:196.

20. Kim J, Kang O, Gweon O. Comparison of phenolic acids and flavonoids in black garlic at different thermal processing steps. $\begin{array}{lll}\text { Funct } & \text { Foods. 2013;5:80-86 }\end{array}$ https://doi.org/10.1016/j.jff.2012.08.006

21. Shin SW, Ghimeray AK, Park CH. Investigation of total phenolic, total flavonoid, antioxidant and allyl isothiocyanate content in the different organs of Wasabi japonica grown in an organic system. Afr J Tradit Complement Altern Med. 2014; 11(3):38-45. https://doi.org/10.4314/ajtcam.v11i3.7

22. Burns RE. Method for Estimation of Tannin in Grain Sorghum Agron J. 1971;63:511-12.

23. Nagata M, Yamashita I. Simple method for simultaneous determination of chlorophyll and carotenoids in tomato fruit. J Japan Soc Food Sci Technol. 1992;39:925-28. https://doi.org/10.3136/nskkk1962.39.925

24. Khatua S, Ghosh S. Acharya K. Chemical composition and biological activities of methanol extract from Macrocybe lobayensis. Journal of Applied Pharmaceutical Science. 2017;7(10):144-51. DOI: 10.7324/JAPS.2017.71021

25. Kulisic T, Radonic A, Katalinic V, Milos M. Use of different method for testing antioxidative activity of oregano essential $\begin{array}{llll}\text { oil. } & \text { Food 2004;85:633-40. }\end{array}$ https://doi.org/10.1016/j.foodchem.2003.07.024

26. Re R, Pellegrini N, Proteggente A, Pannala A, Yang M, Riceevans C. Antioxidant activity applying an improved abts radical cation decolorization assay. Free Radical Biology \& Medicine. 1999;26:1231-37. https://doi.org/10.1016/S0891 5849(98)00315-3
27. Oyaizu M. Studies on products of browning reactions: Antioxidative activities of products of browning reaction prepared from glucosamine. Jpn J Nutr. 1986;44:307-15.

28. Mansur JS, Breder MNR, Mansur MCA, Azulay RD. Determinação Do Fator De Protecao Solar Por Espectrofotometria. An. Bras. Dermatol. 1986;61:121-24.

29. Sayre RM, Agin PP, LeVee GJ, Marlowe E. A comparison of in vivo and in vitro testing of sunscreening formulas. Photochem Photobiol. 1979;29:559-66.

30. Perez C, Pauli M, Bazerque P. An antibiotic assay by the agarwell diffusion method. Acta Biol Med Exper. 1990;15:113-15.

31. National Committee for Clinical Laboratory Standards. Performance standards for antimicrobial disc susceptibility tests. Approved standard NCCLS Publications M2-A5. Villanova, PA, USA. 1993,

32. Ncube NS, Afolayan AJ, Okoh AI. Assessment techniques of antimicrobial properties of natural compounds of plant origin current methods and future trends. Afr J Biotechnol. 2008;7(12):1797-1806. https://doi.org/10.5897/AJB07.613

33. Matijaševic D, Panti M, Raškovi B, Pavlovic V, Duvnjak D, Sknepnek A, Nikšic M. The Antibacterial activity of Coriolus versicolor methanol extract and its effect on ultrastructural changes of Staphylococcus aureus and Salmonella Enteritidis. Front $\quad$ Microbiol $2016 ; 7: 1226$ https://dx.doi.org/10.3389\%2Ffmicb.2016.01226

34. Rajamurugan R, Selvaganabathy N, Kumaravel S, Ramamurthy $\mathrm{CH}$, Sujatha V, Kumar MS, Thirunavukkarasu C. Identification, quantification of bioactive constituents, evaluation of antioxidant and in vivo acute toxicity property from the methanol extract of Vernonia cinerea leaf. Pharm. Biol. 2011;49(12):1311-20.

https://doi.org/10.3109/13880209.2011.604334

35. Costa SCC, Detoni CB, Branco CRC, Botura MB, Branco A. In vitro photoprotective effects of Marcetia taxifolia ethanolic extract and its potential for sunscreen formulation. Revista Brasileira de Farmacognosia. 2015;25:413-18. http://dx.doi.org 10.1016/j.bjp.2015.07.013

36. Schalka S, Steiner D, Ravelli FN, Steiner T, Terena AC, Marcon CR, Ayres EL, Addor FAS, Miot HA, Ponzio H, et al., Brazilian Consensus on Photoprotection. An Bras Dermatol. 2014;89:1 74. http://dx.doi.org/10.1590/abd1806-4841.20143971

37. Napagoda MT, Malkanthi BMAS, Abayawardana SAK, Qader MM, Jayasinghe L. Photoprotective potential insome medicinal plants used to treat skin diseases in Sri Lanka. BMC Complement. $\quad$ Altern. $\quad$ Med. 2016;16:479. https://dx.doi.org/10.1186\%2Fs12906-016-1455-8

38. Osterwalder U, Herzog B. Sun protection factors: worldwide confusion. $\quad \mathrm{Br} \quad \mathrm{J}$ Dermatol. 2009;161: 3-24. https://doi.org/10.1111/j.1365-2133.2009.09506.x

39. Mishra AK, Mishra A, Chattopadhyay P. Assessment of in vitro sun protection factor of Calendula officinalis L. (Asteraceae) essential oil formulation. J Young Pharmacists. 2012;4:17-21. https://dx.doi.org/10.4103\%2F0975-1483.93575

40. Maske PP, Lokapure SG, Nimbalkar D, Malavi S, D’souza JI. In vitro determination of sun protection factor and chemical stability of Rosa kordesii extract gel. J Pharm Res. 2013;7:52024. https://doi.org/10.1016/j.jopr.2013.05.021

41. Ghamba PE, Balla H, Goje LJ, Halidu A, Dauda MD. In vitro antimicrobial activities of Vernonia amygdalina on selected clinical isolates. Int J Curr Microbiol App Sci. 2014;3:1103-13.

42. Muktar B, Bello IA, Sallau MS. Isolation, characterization and antimicrobial study of lupeol acetate from the root bark. J Appl Sci Environ Manage. 2018;22:1129-33. https://doi.org/10.4314/jasem.v22i7.21

43. Hassan LG, Liman MG, Mshelia HE, Ogbiko C, Babagana A Andrew 0 . Lupeol acetate isolated from n-Hexane extract of Tapinanthus globiferus leaf. Chem Search Journal. 2018;9:8388. https://doi.org/10.4314/CSJ.V9I1

44. Cornet I, Wittner N, Tofani G, Tavernier S. FTIR as an easy and fast analytical approach to follow up microbial growth during fungal pretreatment of poplar wood with Phanerochaete chrysosporium. J Microbiol Methods. 2018;145:82-86 https://doi.org/10.1016/j.mimet.2018.01.004

45. Moorthy BT, Ravi S, Srivastava M, Chiruvella KK, Hemlal H, Joy O, Raghavan SC. Novel rhodanine derivatives induce growth inhibition followed by apoptosis. Bioorganic \& Medicinal Chemistry Letters. 2010;20:6297-01. https://doi.org/10.1016/j.bmcl.2010.08.084 
46. Gadhi AAA, El-Sherbiny MMO, Al-Sofyani AMA, Ba-Akdah MA, Satheesh S. Antimicrofouling activities of marine macroalga Dictyota dichotoma from the Red Sea. Journal of Agricultural and Marine Sciences. 2018;23:58-67. http://dx.doi.org/10.24200/ jams.vol23iss0pp58-67

47. Grover N, Patni V. Phytochemical characterization using various solvent extracts and GC- MS analysis of methanolic extract of Woodfordia fruticosa (1.) kurz leaves. Int J Pharm Pharm Sci. 2013;5:291-95.

48. Siddique HR, Saleem M. Beneficial health effects of lupeol triterpene: A review of preclinical studies. Life Sciences. 2011;88:285-93. https://doi.org/10.1016/J.LFS.2010.11.020
49. Gallo MB, Sarachine MJ. Biological activities of lupeol. Int J Biomed Pharm Sci, 2009;3(1):46-66.

50. Tchimene MK, Nwaehujor CO, Ezenwali M, Okoli CC. Iwu MM.. Free radical scavenging activity of lupeol isolated from the methanol leaf extract of Crateva adansonii Oliv. (Capparidaceae). International Journal of Pharmacognosy and Phytochemical Research, 2016;8(3):419-26.

51. Keawsa-ard S, Liawruangrath B. Kongtaweelert S. Bioactive compounds from Mesua ferrea stems. Chiang Mai Journal of Science, 2015;42(1):185-95. 